Volume 11, Nomor 2, November 2019, pp 332-357 Copyright (C) 2017 Jurnal Akuntansi Maranatha, Program Studi Akuntansi, Fakultas Ekonomi, Universitas Kristen Maranatha. ISSN 2085-8698 | e-ISSN 2598-4977. http://journal.maranatha.edu

\title{
Pemeriksaan Operasional Atas Aktivitas Penjualan Pada Hotel Alqueby Untuk Menilai Efektivitas Penjualan
}

\author{
Joey Giovanni Regawa \\ Fakultas Ekonomi, Jurusan Magister Manajemen Bisnis, Universitas Katolik Parahyangan \\ (Jl. Merdeka No. 30, Bandung) \\ joey_regawa@hotmail.com
}

\begin{abstract}
Alqueby Hotel gets profit from renting rooms, restaurant, swimming pool tikets, and gym. Protif is needed so that the hotel can continue to run its operations. Sales activity is the primary activity in the hotel. An ineffective sales activities can cause lack of profit or even losses. So that, writer interested to do operational review on sales activity at Alqueby Hotel. Operational review is a process to analize operational activity to evaluate economic, efficient, and effective from all operation activity in the organization. Method that used in this research is descriptive method. The dependent variable in this research is effectivity, while the independent variable in this research is sales. Data for this research was obtained from two resource, primary resource was obtained through observation to Alqueby Hotel, interview with director, CEO, sales and marketing executive, front office, internal control questionaire, while secondary resource was obtained through organization structure of Alqueby Hotel, job description, income statement Alqueby Hotel, and document that used in sales activity Alqueby Hotel. To overcome those complication, writer gave several recommendation to Alqueby Hotel which is, CEO should allocate tasks with director, Alqueby Hotel should recruit marketing staff and make strategy marketing and plan marketing cost.
\end{abstract}

Keywords: Operational Review, Sales Activity, Effectivity on Sales 


\section{Pendahuluan}

Seiring dengan semakin meningkatnya wisatawan Bandung, kebutuhan akan hotel di Bandung semakin meningkat juga. Saat ini bisnis hotel di Bandung merupakan salah satu usaha yang sangat menjanjikan sehingga jumlah hotel di Bandung semakin bertambah. Menurut Ketua Perhimpunan Hotel dan Restoran Indonesia (PHRI) Jawa Barat Herman Muchtar, jumlah hotel di Bandung mencapai 473 dengan total kamar sebanyak 26.000 unit. Pada awal tahun 2016, terdapat sekitar 30 hotel baru yang sedang dibangun sehingga pada akhir 2016 jumlahnya diperkirakan bertambah menjadi 500 hotel yang mencakup 30.000 kamar.Salah satu hotel yang terletak di kota Bandung yaitu Hotel Alqueby. Hotel Alqueby adalah hotel bintang dua yang terletak di Bandung Timur yaitu di Jalan Terusan Jakarta Utara No 7, Antapani. Hotel Alqueby merupakan hotel budget bintang dua. Hotel budget yaitu hotel yang menawarkan tarif yang cukup murah.

Hotel mendapatkan laba dari aktivitas sewa kamar dan penjualan pada restoran, kolam renang, atau gym. Laba dibutuhkan agar hotel dapat terus menjalankan kegiatan operasinya. Manajemen hotel harus memastikan agar penjualan pada hotel tidak menurun sehingga tidak terjadi kerugian yaitu dengan cara pemberian jasa yang memuaskan bagi tamu, pemasaran yang efektif, dan fasilitas hotel yang memuaskan. Selain itu, kerugian juga dapat terjadi jika keseluruhan aktivitas penjualan tidak dilaksanakan dengan efektif, sehingga dapat terjadi kecurangan yang dilakukan oleh karyawan hotel atau kesalahan dalam pencatatan.

Berdasarkan uraian di atas, dapat disimpulkan bahwa aktivitas penjualan merupakan aktivitas utama pada usaha hotel dan akan menjadi penentu keberlangsungan hidup hotel. Aktivitas penjualan yang tidak efektif dapat berakibat pada menurunnya penjualan, kerugian, bahkan dapat berakhir pada kebangkrutan. Oleh karena itu, mengingat pentingnya aktivitas penjualan bagi hotel, penulis tertarik untuk melakukan pemeriksaan operasional terhadap aktivitas penjualan di Hotel Alqueby.

\section{Rumusan Masalah:}

Berdasarkan latar belakang penelitian, penulis merumuskan masalah yang terdapat pada Hotel Alqueby adalah sebagai berikut:

1. Apakah kebijakan dan prosedur yang terkait dengan proses penjualan yang terdapat dalam Hotel Alqueby sudah disusun dengan benar dan sudah diimplementasi dengan baik?

2. Apakah pengendalian internal yang terdapat pada Hotel Alqueby sudah memadai dan sudah diimplementasikan dengan baik?

3. Bagaimana pencapaian target penjualan pada Hotel Alqueby?

\section{Manfaat Penelitian:}

Penulis berharap dengan dilaksanakannya penelitian ini dapat memberikan manfaat sebagai berikut:

\section{Bagi Perusahaan}

Penulis berharap dengan dilakukannya penelitian ini dapat membantu Hotel Alqueby untuk menemukan kelemahan yang terdapat dalam aktivitas penjualannya dan dapat memberikan rekomendasi yang sesuai dengan kelemahan tersebut sehingga dapat membantu manajemen hotel dalam memperbaiki kinerja penjualan pada Hotel Alqueby. Diharapkan setelah Hotel Alqueby melaksanakan rekomendasi yang diberikan oleh penulis, Hotel Alqueby dapat memberikan pelayanan yang lebih baik kepada pelanggan dan menyediakan fasilitas yang memuaskan sehingga dapat meningkatkan penjualan.

2. Bagi pembaca

Dengan dilakukannya penelitian ini, penulis berharap bahwa penelitian ini dapat memberikan pengetahuan bagi pembaca mengenai proses penjualan pada hotel. Pembaca juga dapat 
mengetahui langkah-langkah untuk melakukan pemeriksaan operasional terdapat kinerja penjualan pada hotel. Selain itu, penelitian ini juga dapat menjadi referensi bagi pembaca jika pembaca menemukan masalah yang sejenis dalam proses penjualan pada hotel.

3. Bagi penulis

Penulis berharap dengan dilaksanakannya penelitian ini, dapat lebih memahami dan mendalami teoriteori Audit Manajemen yang telah dipelajari selama proses perkuliahan dan dapat menerapkannya di lapangan. Penelitian ini juga bermanfaat untuk menambah pengalaman penulis mengenai proses Audit Manajemen dan menambah pengetahuan dan wawasan penulis mengenai proses penjualan dalam hotel.

\section{Kerangka Teoritis}

\section{Pemeriksaan Operasional}

Pemeriksaan operasional penting untuk dilakukan oleh suatu organisasi untuk menilai apakah kinerja operasional pada organisasi tersebut sudah berjalan dengan efektif dan efisien, sesuai dengan tujuan yang telah ditetapkan. Pemeriksaan operasional juga diperlukan untuk mengetahui kelemahan-kelemahan yang terdapat dalam kinerja suatu organisasi sehingga dapat dicari solusi agar permasalahan yang terjadi dapat diatasi.

Pemeriksaan operasional merupakan proses untuk menganalisis kegiatan operasional dan aktivitas yang terdapat di perusahaan untuk dievaluasi mengenai ekonomis, efisiensi, dan efektifitas dari seluruh kegiatan operasional perusahaan. (Reider (2002:2-3), Arens, dkk (2013:893)

\section{Efektivitas, Efisiensi, dan Ekonomis}

Sebelum pemeriksaan operasional dilaksanakan, pemeriksa harus merancang kriteria untuk mengukur efektivitas.
Menurut Arens, dkk (2014:834), pengertian efektivitas merujuk pada hasil yang sesuai dengan tujuan, seperti memproduksi barang tanpa cacat. Sedangkan efisiensi menurut Reider (2001:21) mengarah pada penggunaan metode operasi sumber daya seminimal mungkin untuk mencapai tujuan. Menurut Reider (2002:21), ekonomis adalah ketika perusahaan menggunakan cara-cara yang paling ekonomis untuk menghemat biaya sumber daya.

\section{Hotel}

Hotel merupakan bangunan yang menyediakan jasa kamar untuk jangka pendek, makanan, minuman, dan jasa lain yang diperlukan dengan imbalan pembayaran dari para tamu. Hotel dapat digunakan oleh para tamu untuk kepentingan liburan maupun bisnis.

Hotel adalah suatu usaha yang bergerak di bidang akomodasi yang dikelola secara profesional guna menghasilkan keuntungan dengan menyediakan pelayanan makanan, minuman, dan fasilitas kamar untuk tidur kepada orang-orang yang melakukan perjalanan dan membayar dengan jumlah yang sesuai dengan pelayanan yang diterima. (Endar \& Sulartiningrum (1996:8); Utama(2016:43))

\section{Penjualan}

Penjualan merupakan aktivitas penting dari suatu perusahaan karena dari penjualan perusahaan akan mendapat keuntungan untuk menutup biaya operasional yang terjadi dan diharapkan dapat memberikan pengembalian modal yang cukup untuk pemilik. Oleh karena itu, harus dilakukan pemeriksaan operasional atas aktivitas penjualan agar aktivitas penjualan dapat meningkatkan penjualan perusahaan.

Penjualan adalah perpindahan hak milik atas barang atau jasa yang dilakukan oleh penjual kepada pembeli dan penjual mempengaruhi pembeli agar bersedia membeli barang yang ditawarkan. (Rangkuti (2009:206) ; Basu Swastha (2014:8)) 


\section{Pemeriksaan Operasional atas Penjualan}

Pemeriksaan operasional atas penjualan dilakukan agar dapat mengetahui kelemahan yang terdapat pada aktivitas penjualan. Kelemahan pada aktivitas penjualan ditandai dengan tidak dapat mencapai target penjualan. Kelemahan pada aktivitas penjualan jika dibiarkan berlarutlarut dapat berakibat penurunan tingkat penjualan dan akan berdampak pada penurunan profit. Sehingga pemeriksaan operasional atas penjualan perlu dilaksanakan untuk memastikan aktivitas penjualan sudah dilaksanakan dengan efektif dan efisien.

\section{Kerangka Pemikiran}

Menurut Endar (1996:8), hotel adalah suatu bangunan yang dikelola secara komersil guna memberikan fasilitas penginapan kepada masyarakat umum dengan fasilitas penginapan kepada masyarakat umum dengan fasilitas antara lain: jasa penginapan, pelayanan barang bawaan, pelayanan makanan dan minuman, penggunaan fasilitas perabot, dan hiasanhiasan yang ada di dalamnya serta jasa pencuci pakaian.

Aspek terpenting dalam bisnis perhotelan yaitu aktivitas penjualan. Aktivitas penjualan merupakan aktivitas utama dalam perusahaan yang berorientasi laba. Aktivitas penjualan pada hotel dimulai ketika tamu melakukan pemesanan atau booking kamar dan diakhiri ketika tamu check-out. Banyak faktor yang dapat menyebabkan penjualan kamar hotel berkurang, salah satunya yaitu aktivitas penjualan yang kurang efektif. Aktivitas penjualan yang kurang efektif dapat ditandai dengan struktur organisasi yang lemah, prosedur yang tidak jelas sehingga menyebabkan karyawan hotel tidak dapat melakukan pekerjaan dengan baik, pengendalian internal yang tidak efektif, dan lain-lain. Oleh karena itu, pemeriksaan operasional penting dilakukan untuk mendeteksi kelemahan-kelemahan yang terdapat pada aktivitas penjualan dan merancang tindakan perbaikan dapat dilakukan untuk mengatasi aktivitas penjualan yang kurang efektif pada Hotel Alqueby.

Pemeriksaan operasional menurut Reider (2002:3) adalah pemeriksaan dari operasi yang dilaksanakan dari sudut pandang manajemen untuk mengevaluasi efektivitas, efisiensi, dan nilai ekonomis dari semua operasi. Ada tiga tujuan pemeriksaan operasional menurut Reider (2002:3) yaitu: pertama, untuk menilai kinerja. Penilaian kinerja ini dilakukan dengan membandingkan aktivitas operasional dengan tujuan yang ditetapkan oleh manajemen, selain itu, dapat juga dilakukan dengan membandingkan aktivitas operasional dengan fungsi yang sama dalam suatu organisasi (internal benchmarking), yang terakhir adalah dengan membandingkan dengan organisasi sejenis di luar perusahaan (external benchmarking). Tujuan yang kedua adalah untuk mengidentifikasi peluang untuk perkembangan. Tujuan yang ketiga adalah untuk membuat rekomendasi untuk menunjang perbaikan. Pemeriksa operasional terus-menerus mencari cara yang terbaik untuk menunjang continuous improvement.

Lebih lanjut menurut Reider (2002:3), pemeriksaan operasional berkonsep untuk membuat suatu operasi menjadi ekonomis, efisien, dan efektif. Ekonomis berarti organisasi mengambil keputusan yang paling ekonomis dalam hal mengatur sumber daya. Efisien berarti organisasi menjalankan kewajiban dengan usaha yang secukupnya, yang berarti tidak membuang-buang usaha atau sumber daya yang sebenarnya tidak diperlukan. Sedangkan efektif berarti organisasi mencapai tujuan sesuai dengan tujuan yang telah ditetapkan.

Reider (2002:3) mengemukakan bahwa pemeriksaan operasional memiliki lima fase, yang pertama adalah planning. Pada tahap planning ini pemeriksa operasional mengumpulkan informasi 
mengenai area operasional dari suatu organisasi, misalnya peraturan dalam organisasi, material dalam suatu organisasi (struktur organisasi, job description), informasi keuangan, prosedur-prosedur yang berlaku, informasi manajemen, dan laporan manajemen. Lalu pada tahap planning ini juga pemeriksa operasional mengidentifikasi kemungkinan problem area, lalu membuat basis untuk pengerjaan work program. Tahap kedua dari pemeriksaan operasional adalah work program. Pada tahap ini, pemeriksa operasional fokus pada operasional tertentu yang telah diidentifikasi pada tahap planning dan membuat langkah kerja yang spesifik untuk pemeriksaan dan analisa lebih lanjut. Pemeriksa operasional memilih beberapa teknik yang akan digunakan, misalnya dengan melakukan review dokumen-dokumen, menganalisis SOP dalam suatu organisasi, melihat rasio laporan keuangan, memberikan kuesioner, survey dan lain-lain. Tahap yang ketiga yaitu field work. Pada tahap ini, informasi tambahan dikumpulkan terkait dengan manajemen dan pengendalian operasional untuk mengidentifikasi pada bidang apakah yang sebaiknya ditinjau lebih dalam. Pada tahap field work pula, langkah-langkah yang telah ditetapkan pada fase work program dikerjakan. Langkah selanjutnya adalah development of review findings. Terdapat lima atribut dari review findings, yang pertama adalah statement of condition, menjelaskan kondisi apa yang merupakan kelemahan yang ditemukan oleh pemeriksa, yang kedua adalah criteria, menjelaskan apa yang seharusnya terjadi, SOP apa yang mendasari kegiatan tersebut, yang ketiga adalah cause, menjelaskan mengapa kelemahan tersebut terjadi, yang keempat adalah effect, menjelaskan apa dampak yang terjadi akibat terdapat kelemahan dalam pelaksaan operasional tersebut, dan yang terakhir adalah recommendation, yaitu pemeriksa pemberikan rekomendasi untuk memperbaiki kelemahan tersebut. Tahap yang terakhir dari pemeriksaan operasional yaitu reporting. Pada tahap ini pemeriksa membuat laporan yang sesuai dengan hasil pemeriksaan.

Dengan dilakukannya pemeriksaan operasional terhadap aktivitas penjualan pada Hotel Alqueby, diharapkan penulis dapat menemukan kelemahan-kelemahan sehingga penulis dapat memberikan saran dan rekomendasi yang membangun untuk meningkatkan efektivitas aktivitas penjualan Hotel Alqueby.

\section{Metode Penelitian}

Penelitian menurut Sekaran dan Bougie (2013:2) adalah proses menemukan solusi untuk masalah setelah dilakukan studi dan analisis terhadap faktor-faktor terkait. Terdapat tiga metode penelitian menurut Sekaran dan Bougie (2013:96) yaitu explanatory, descriptive, dan causal. Metode penelitian yang digunakan dalam pemeriksaan ini adalah deskriptif. Metode penelitian deskriptif menurut Sekaran dan Bougie (2013:97-98) merupakan metode yang memberi deskripsi atas karakteristik personel, kejadian, atau situasi sehingga dapat memberikan gambaran kepada peneliti untuk mengetahui kelemahan apa yang terdapat dalam operasional suatu perusahaan dan membantu peneliti dalam membuat rekomendasi yang sesuai. Penelitian deskriptif dapat dilakukan secara kuantitatif atau kualitatif. Penelitian deskriprif menurut Sekaran dan Bougie (2013:97-98) bertujuan untuk membantu peneliti untuk memahami karakteristik dari suatu organisasi, berpikir sistematis, memberikan gagasan untuk melakukan penelitian, dan membantu peneliti membuat keputusan. 


\section{Sumber Data}

Data dalam penelitian ini dapat didapatkan dari dua sumber, yaitu:

1. Sumber primer

$\begin{array}{llll}\text { Menurut } & \text { Sekaran dan } & \text { Bougie } \\ (2013: 113) & \text { sumber } & \text { data } & \text { primer }\end{array}$ merupakan data yang didapatkan langsung oleh peneliti. Data primer didapatkan penulis melalui wawancara dengan direktur hotel, observasi ke lokasi hotel, mengedarkan kuesioner kepada pelanggan hotel, dan lain-lain.

2. Sumber sekunder

Sumber sekunder menurut Sekaran dan Bougie (2013:113) merupakan data yang didapatkan dari sumber yang telah tersedia. Data sekunder didapatkan penulis melalui laporan keuangan hotel, struktur organisasi, job description, dan data mengenai jenis kamar dan fasilitas hotel.

\section{Teknik Pengolahan Data}

Menurut Sekaran dan Bougie (2013:274), teknik pengolahan data dibagi menjadi 2 , yaitu:

1. Analisis Kuantitatif

Analisis kuantitatif merupakan analisis data yang berupa data angka. Analisis ini berfungsi untuk memastikan bahwa data telah akurat, lengkap, dan cocok untuk dilakukan analisa selanjutnya. Untuk melakukan analisis kuantitatif, penulis melakukan analisis target penjualan dengan penjualan aktual pada Hotel Alqueby dari tahun 2015 hingga 2016.

2. Analisis Kualitatif

Analisis kualitatif merupakan pengolahan data yang berbentuk lisan/ kata-kata. Data yang berbentuk katakata perlu dianalisis agar tidak terjadi kelebihan data. Analisis kualitatif ini dilakukan penulis dengan cara melakukan wawancara dengan pihak yang berhubungan dengan aktivitas penjualan, mengevaluasi pelaksanaan pengendalian internal Hotel Alqueby, risk and control matrix, analisis dari sistem informasi akuntansi aktivitas pendapatan Hotel Alqueby, walkthrough, dan flowchart.

\section{Hasil Penelitian dan Pembahasan}

Pemeriksaan operasional merupakan proses menganalisis aktivitas dan operasional internal untuk mengidentifikasikan area untuk perbaikan terus menerus. Pemeriksaan operasional dilakukan dengan membandingkan kinerja sebenarnya dengan kinerja yang seharusnya sesuai dengan standar, prosedur, dan kebijakan yang telah ditetapkan oleh perusahaan. Pada bab ini, penulis akan membahas gambaran yang sebenarnya mengenai aktivitas operasional yang dilakukan oleh Hotel Alqueby dan membandingkannya dengan standar, prosedur dan kebijakan yang telah ditetapkan dan mengetahui kelemahan yang terdapat dalam opearasional hotel. Setelah itu, penulis akan memberikan rekomendasi yang tepat untuk mengatasi kelemahankelemahan tersebut.

Ruang lingkup dalam penelitian ini adalah aktivitas penjualan. Aktivitas penjualan merupakan aktivitas terpenting dari suatu perusahaan yang bertujuan untuk mencapai laba. Penurunan penjualan dapat menyebabkan penurunan pendapatan dan dapat juga mengakibatkan kebangkrutan. Aktivitas operasional yang tidak baik dapat berdampak pada penurunan penjualan. Oleh karena itu, perusahaan harus melaksanakan aktivitas operasional dengan sebaik-baiknya agar dapat mendukung peningkatan penjualan.

Dalam melakukan pemeriksaan operasional ini, penulis menggunakan beberapa tahap dalam pemeriksaan operasional, yaitu:

\section{Planning Phase (Tahap Perencanaan)}

Tahap perencanaan merupakan langkah pertama untuk memulai pemeriksaan operasional. Dalam tahap ini, pemeriksa mengenal kegiatan operasi yang terdapat 
dalam Hotel Alqueby. Pada tahap ini pula pemeriksa menentukan critical area dan critical problem yang terdapat dalam kegiatan operasional Hotel Alqueby. Critical area adalah bidang yang memiliki potensi masalah sehingga harus dilakukan pencegahan agar tidak terjadi masalah di masa yang akan datang sedangkan critical problem adalah bidang yang sudah menjadi masalah sehingga harus dilakukan tindakan perbaikan. Pemeriksa mendapatkan informasi untuk tahap ini dari berbagai cara, seperti wawancara dengan direktur Hotel Alqueby untuk memperoleh gambaran umum mengenai kegiatan operasional di Hotel Alqueby, observasi ke Hotel Alqueby, dengan meminta dokumendokumen yang dipakai oleh Hotel Alqueby, dan struktur organisasi Hotel Alqueby.

Berdasarkan hasil wawancara dengan CEO Hotel Alqueby didapatkan informasi bahwa Hotel Alqueby merupakan hotel bintang dua dan memiliki 73 kamar. Hotel Alqueby menawarkan empat jenis kamar, yaitu executive room, deluxe room, superior + , dan superior room. Perbedaan keempat jenis kamar itu terletak pada luas kamar, jenis kasur, dan fasilitas yang tersedia. Tarif termurah yaitu pada tipe kamar superior room dan tarif termahal pada excecutive room. Tarif kamar berbeda pada hari biasa dan akhir pekan, Hotel Alqueby juga menawarkan tarif yang berbeda untuk rombongan.

Hotel Alqueby memiliki 40 karyawan. Untuk room attendant, bagian front desk, dan waiter, terdapat 3 shift dengan jam kerja 8-9 jam per shift, yaitu pagi jam 7.00-15.00, siang jam 15.0023.00, malam jam 23.00-07.00. Sebagian besar tamu hotel menginap untuk tujuan wisata di Bandung, sedangkan hanya terdapat sebagian kecil tamu yang menginap untuk tujuan pekerjaan. Terdapat paling sedikit satu rombongan dalam satu bulan, untuk tujuan wisata. Hotel Alqueby pula kadang-kadang dipilih untuk tempat penginapan jika ada acara di Bandung seperti Pekan Olahraga Nasional. Kamar tipe superior room juga merupakan tipe kamar yang paling laku karena menawarkan tarif yang paling murah. Penjualan kamar juga lebih banyak pada akhir pekan dibandingkan dengan hari biasa.

Dari struktur organisasi diketahui bahwa Hotel Alqueby tidak mempunyai staff untuk divisi pemasaran. Bagian pemasaran saat ini hanya dipegang oleh satu orang saja, sehingga kegiatan pemasaran di Hotel Alqueby tidak berjalan dengan optimal. Ketika Hotel Alqueby pertama didirikan yaitu pada tahun 2013, divisi pemasaran memiliki 2 staff, tetapi staff tersebut mengundurkan diri pada tahun 2015 dan belum dicari penggantinya, pada tahun 2013 hingga 2015, kegiatan pemasaran dilakukan dengan cara iklan di radio, mengedarkan selebaran, dan melalui media sosial seperti Facebook dan Instagram. Tetapi, akhir-akhir ini, kegiatan pemasaran hanya melalui pameran hotel saja, Hotel Alqueby mengandalkan promosi melalui mulut ke mulut, yaitu pelanggan yang puas akan menceritakan pengalaman baik selama menginap di Hotel Alqueby dan diharapkan dapat mengundang pelanggan baru. Selain itu, dari struktur organisasi juga diketahui bahwa terdapat banyak pekerjaan rangkap yang terdapat dalam Hotel Alqueby, seperti CEO dalam Hotel Alqueby merangkap sebacai akuntan, supervisor dan juga sebagai human resource department. Hal ini dapat mengakibatkan CEO terlalu terpaku pada rutinitas sehingga tidak memiliki waktu untuk melakukan pengembangan pada hotel.

Keunggulan Hotel Alqueby dibandingkan dengan hotel lainnya yaitu tarif yang murah tetapi kualitas yang baik. Jika dibandingkan dengan hotel budget bintang dua lainnya di Bandung, tarif yang ditawarkan Hotel Alqueby lebih murah. Saingan terbesar Hotel Alqueby yaitu Hotel Ideas yang terletak tidak jauh dari Hotel Alqueby yaitu di daerah Kiara Condong. Hotel Ideas lebih baru daripada Hotel Alqueby, dan menurut CEO Hotel Alqueby, 
dengan adanya Hotel Ideas tidak berdampak kepada tingkat okupansi Hotel Alqueby. Sedangkan saingan Hotel Alqueby yang lain adalah hotel budget seperti Amaris, Ibis Budget. Bila dibandingkan dengan Amaris dan Ibis Budget, meskipun Hotel Alqueby memiliki tarif yang lebih murah, tetapi kedua hotel tersebut berlokasi di tengah kota sehingga banyak tamu yang memilik untuk menginap di kedua hotel tersebut walaupun menawarkan tarif yang lebih mahal.

Sedangkan berdasarkan observasi yang dilakukan oleh penulis, Hotel Alqueby terletak di Jalan Terusan Jakarta Utara nomor 7. Lokasi hotel di pinggir jalan dan mudah ditemukan, tetapi, letak hotel lumayan jauh dari tengah kota dan berada di daerah yang macet. Hotel Alqueby menyediakan lapangan parkir yang cukup untuk 30 mobil, dengan tukang parkir yang sigap untuk memarkirkan mobil tamu ketika tamu datang. Lobby hotel tidak begitu luas dan hanya terdapat dua kursi untuk menunggu di lobby, sehingga ketika banyak tamu datang ke hotel, hanya dua tamu yang dapat dudukdi kursi sedangkan yang lainnya harus berdiri. Cafe terletak persis disebelah lobby, namun, kapasitas cafe sangat terbatas karena hanya terdapat 7 meja di dalam cafe tersebut.

Pada saat tamu melakukan pemesanan kamar, front office melayani tamu dengan ramah dan dapat menjelaskan tipe-tipe kamar kepada tamu dengan baik dengan ramah. Tamu yang sudah selesai melakukan check-in, tamu langsung diantar oleh room attendant ke kamar. Kamar hotel bersih dan fasilitas yang tersedia di dalam kamar berjalan dengan baik.

Dari hasil wawancara dan observasi yang dilakukan, penulis menemukan beberapa masalah dalam Hotel Alqueby, yaitu:

a. Hotel Alqueby sering tidak mencapai target penjualan.

Target penjualan kamar disusun berdasarkan keinginan pemilik untuk breakevent point. b. Kurangnya staff dalam divisi sales and marketing.

Hal ini menyebabkan tidak optimalnya kegiatan pemasaran yang dilakukan sehingga dapat berdampak pada penjualan yang kecil.

c. Promosi Hotel Alqueby tidak dilakukan secara gencar.

Saat ini promosi Hotel Alqueby hanya pada media sosial saja, itu pun kurang optimal ditinjau dari target market Hotel Alqueby yaitu untuk keluarga dari kalangan menengah ke bawah yang ingin berwisata di Bandung, tetapi tidak semua orang tua memiliki media sosial dan promosi melalui media sosial ini kurang gencar, dinilai dari Instagram Hotel Alqueby yang jarang diupdate.

d. Kurangnya pemisahan fungsi pada Hotel Alqueby.

Hal ini dilihat dari tidak adanya divisi human resource dan accounting, sehingga semua kegiatan dilakukan oleh CEO, hal ini dapat mengakibatkan CEO terlalu sibuk pada rutinitas dan tidak mempunyai waktu untuk pengembangan hotel, dan tidak ada yang melakukan pemeriksaan atas perhitungan.

e. Lokasi hotel kurang strategis

Lokasi hotel terletak di Antapani, yaitu jauh dari tengah kota dan terletak di daerah macet sehingga banyak pengunjung yang lebih memilih untuk menginap di hotel di tengah kota walaupun menawarkan harga lebih mahal dan fasilitas yang lebih buruk.

f. Kurangnya fasilitas di Hotel Alqueby.

Hal ini ditunjukan dengan kurangnya ruang tunggu pada lobby dan kapasitas cafe yang terbatas.

Berdasarkan masalah-masalah yang telah diuraikan diatas, penulis mengambil kesimpulan bahwa yang menjadi critical area adalah aktivitas penjualan. Penjualan termasuk kedalam critical area dan belum menjadi critical problem karena tidak terjadi penurunan pada penjualan yang signifikan dari tahun ke tahun, tetapi, penjualan terlihat stabil, tidak adanya 
peningkatan. Hal ini mengindikasikan bahwa aktivitas penjualan kurang efektif. Penulis melakukan pemeriksaan operasional terhadap aktivitas penjualan, sehingga dapat mengatasi permasalahan yang terdapat dalam aktivitas penjualan.

Tujuan penulis melakukan pemeriksaan operasional ini adalah:

a. Mengetahui bahwa kebijakan dan prosedur yang terkait dengan proses penjualan yang terdapat dalam Hotel Alqueby sudah disusun dengan benar dan sudah diimplementasi dengan baik.

b. Mengetahui bahwa pengendalian internal yang terdapat pada Hotel Alqueby sudah memadai dan sudah diimplementasi dengan baik.

c. Mengevaluasi pencapaian target penjualan pada Hotel Alqueby.

\section{Work Program Phase (Tahap Program Kerja)}

Setelah menetapkan critical area, langkah selanjutnya adalah tahap program kerja. Tahap program kerja ini merupakan rencana kerja yang akan dilakukan untuk melaksanakan pemeriksaan operasional.

Berikut ini merupakan langkah-langkah kerja yang akan dilakukan oleh peneliti:

a. Analisis dari sistem informasi akuntansi aktivitas pendapatan Hotel Alqueby.

Tujuan: untuk mengevaluasi apakah aktivitas pendapatan telah dijalankan dengan baik dan kelemahan apa saja yang terdapat pada aktivitas pendapatan Hotel Alqueby.

b. Wawancara dengan pihak yang berhubungan dengan aktivitas penjualan.

Tujuan: untuk mengetahui kelemahan dan kesulitan apa yang dirasakan oleh pihak yang berhubungan dengan aktivitas penjualan agar dapat dicarikan solusinya.

c. Mengevaluasi pelaksanaan pengendalian internal Hotel Alqueby.

Tujuan: untuk mengetahui apakah pengendalian internal sudah dijalankan dengan baik. d. Analisis target penjualan dengan penjualan aktual pada Hotel Alqueby dari tahun 2015 hingga 2016.

Tujuan: untuk mengetahui apakah aktivitas penjualan sudah dilakukan dengan efektif. Aktivitas penjualan dikatakan efektif bila penjualan aktual telah mencapai target penjualan.

Penulis juga mengevaluasi design dari pengendalian internal yang terdapat di Hotel Alqueby, apakah pengendalian tersebut sudah efektif untuk menghadapi permasalahan yang terdapat di dalam Hotel Alqueby. Tujuannya untuk mengidentifikasi risiko untuk mencapai tujuan manajemen, mengidentifikasi pengendalian dan teknik lain yang digunakan untuk menghadapi risiko, dan mengevaluasi perancangan dari teknik tersebut.

Penulis akan mengevaluasi design pengendalian dari Hotel Alqueby dengan menggunakan tiga teknik, yaitu:

a. Risk/control matrix

Teknik ini digunakan untuk mengetahui tujuan yang ingin dicapai dari aktivitas penjualan Hotel Alqueby, mengetahui inherent risk yang terdapat dalam aktivitas penjualan Hotel Alqueby, mengetahui kemungkinan terjadinya risiko, dan aktivitas apa yang dilakukan untuk mencegah terjadinya risiko tersebut.

b. Flowchart

Teknik ini digunakan untuk mengetahui sistem penjualan Hotel Alqueby, mengetahui pengendalian yang digunakan pada tiap aktivitas, dan menilai apakah pengendalian tersebut sudah dirancang dengan baik dan berjalan dengan efektif.

c. Walk-through

Teknik ini digunakan untuk mengetahui apakah pegawai di Hotel Alqueby sudah melakukan pekerjaannya sesuai dengan prosedur yang berlaku dan evaluasi dokumen yang terdapat di Hotel Alqueby apakah dokumen tersebut memiliki pengendalian yang memadai. 


\section{Risk/control matrix}

Pertama-tama penulis akan menggunakan risk/control matrix untuk menilai risiko yang terdapat pada Hotel Alqueby. Penulis mengisi matrix dengan melakukan wawancara pada CEO karena CEO pada Hotel Alqueby mengepalai langsung aktivitas penjualan, CEO mengetahui apa yang menjadi tujuan dari aktivitas penjualan Hotel Alqueby, dan risiko apa saja yang terdapat pada aktivitas penjualan tersebut. Selain itu juga penulis melakukan wawancara kepada front office, dan observasi ke Hotel Alqueby.

Berikut ini merupakan langkah-langkah untuk membuat risk/control matrix:

a. Mengidentifikasi tujuan

Langkah pertama dari membuat risk/control matrix adalah mengidentifikasi tujuan aktivitas penjualan Hotel Alqueby. Adapun tujuan dari aktivitas penjualan pada Hotel Alqueby yaitu:

1) Aktivitas penjualan dilakukan dengan baik.

Tujuan pertama yaitu aktivitas penjualan dilakukan dengan baik. Aktivitas penjualan telah dilakukan dengan baik jika proses pencatatan pada dokumen sudah benar dan aktivitas penjualan dilaksanakan sesuai dengan SOP yang berlaku.

2) Memastikan keluhan tamu dapat ditanggapi dengan cepat.

Jika terdapat sesuatu yang menyebabkan tamu tidak puas, Hotel Alqueby harus menanggapi keluhan tamu dengan cepat sehingga Hotel Alqueby dapat mempertahankan nama baiknya dan tidak menurunkan kepuasan tamu.

3) Mengoptimalkan fasilitas hotel agar dapat dinikmati oleh tamu hotel.

Fasilitas yang terdapat di Hotel Alqueby harus sesuai dengan fasilitas yang dijanjikan, fasilitas hotel harus tetap dijaga dan dilakukan perbaikan terus-menerus agar tidak terjadi keusangan dan kebersihan hotel harus dijaga.

b. Mengidentifikasi Inherent Risk Langkah kedua dari teknik ini adalah penulis akan mengidentifikasi risiko yang terdapat dari masing-masing tujuan yang dapat mencegah pencapaian tujuan tersebut. Berikut ini merupakan inherent risk yang terdapat dari masingmasing tujuan:

Tabel 1

Inherent Risk

\begin{tabular}{|c|c|}
\hline Tujuan & Inherent Risk \\
\hline \multirow[t]{3}{*}{$\begin{array}{l}\text { Aktivitas Penjualan dilakukan } \\
\text { dengan baik }\end{array}$} & $\begin{array}{l}\text { Tamu yang melakukan check-in } \\
\text { tidak terdaftar }\end{array}$ \\
\hline & $\begin{array}{l}\text { Terdapat standar operational } \\
\text { procedure untukmelayani tamu } \\
\text { tetapi tidak dilaksanakan } \\
\text { dengan baik }\end{array}$ \\
\hline & $\begin{array}{l}\text { Front office tidak bisa } \\
\text { menjawab pertanyaan yang } \\
\text { diajukan tamu sehubungan } \\
\text { dengan prosedur check-in/ } \\
\text { check-out, tipe kamar dan } \\
\text { fasilitas hotel }\end{array}$ \\
\hline \multirow{2}{*}{$\begin{array}{l}\text { Memastikan keluhan tamu } \\
\text { ditanggapi dengan cepat dan } \\
\text { baik }\end{array}$} & $\begin{array}{l}\text { Front office sulit dihubungi } \\
\text { oleh tamu yang telepon kamar }\end{array}$ \\
\hline & $\begin{array}{l}\text { Jika ada keluhan mengenai } \\
\text { fasilitas kamar, perbaikan } \\
\text { tidak dapat dilakukan dengan } \\
\text { segera }\end{array}$ \\
\hline \multirow[t]{2}{*}{$\begin{array}{l}\text { Mengoptimalkan fasilitas hotel } \\
\text { agardapat dinikmati oleh tamu }\end{array}$} & $\begin{array}{l}\text { Fasilitas hotel yang sudah } \\
\text { using fidak terdeteksi dengan } \\
\text { segera }\end{array}$ \\
\hline & Kebersihan hotel \\
\hline
\end{tabular}

Sumber: Olahan Penulis

c. Assess risk impact and likelihood (menilai dampak risiko tersebut dan kemungkinan terjadinya)

Pada tahap ini penulis menilai kemugkinan terjadinya masing-masing inherent risk yang telah dijelaskan pada tahap sebelumnya dan dampak jika risiko tersebut terjadi. Dampak mengacu pada bagaimana pengaruh risiko tersebut terhadap tujuan aktivitas penjualan Hotel Alqueby. Kemungkinan terjadi/ frekuensi mengacu pada seberapa sering risiko tersebut terjadi. Penulis juga menyajikan bagaimana respon yang diambil dari masing-masing risiko.

Pada tabel di bawah ini akan dijelaskan mengenai tingkatan dampak risiko dan penjelasannya: 
Tabel 2

Dampak Risiko

\begin{tabular}{|l|l|}
\hline \multicolumn{1}{|c|}{ Tingkatan } & \multicolumn{1}{c|}{ Penjelasan } \\
\hline High & $\begin{array}{l}\text { Risiko ini memiliki pengaruh } \\
\text { yang besar terhadap aktivitas } \\
\text { penjualan }(>50 \%)\end{array}$ \\
\hline Medium & $\begin{array}{l}\text { Risiko ini memiliki pengaruh } \\
\text { yang sedang terhadap } \\
\text { aktivitas penjualan }(20 \%-50 \%)\end{array}$ \\
\hline Low & $\begin{array}{l}\text { Risiko ini memiliki pengaruh } \\
\text { yangkecil jerhadap altivitas } \\
\text { penjualan }(<20 \%)\end{array}$ \\
\hline
\end{tabular}

Sumber: Olahan Penulis

Pada tabel di bawah ini akan dijelaskan mengenai tingkatan frekuensi terjadinya risiko dan penjelasannya:

Tabel 3

Frekuensi

\begin{tabular}{|l|l|}
\hline \multicolumn{1}{|c|}{ Tingkatan } & \multicolumn{1}{c|}{ Penjelasan } \\
\hline High & $\begin{array}{l}\text { Risiko ini sangat sering/ hampir } \\
\text { pasti terjadi }\end{array}$ \\
\hline Medium & $\begin{array}{l}\text { Risiko ini tidak terlalu sering } \\
\text { terjadi }\end{array}$ \\
\hline Low & Risiko ini jarang terjadi \\
\hline
\end{tabular}

\section{Sumber: Olahan Penulis}

Selanjutnya pada tabel di bawah ini akan dijelaskan mengenai tindakan yang dapat diambil sebagai respon manajemen dari suatu risiko beserta penjelasannya:

Tabel 4

Respon

\begin{tabular}{|c|c|}
\hline Tingkatan & Penjelasan \\
\hline $\begin{array}{l}\text { Avoidancel } \\
\text { Benghindaran }\end{array}$ & $\begin{array}{l}\text { Menghilang gan aktivitas yang } \\
\text { dapat menimbulkan risiko }\end{array}$ \\
\hline $\begin{array}{l}\text { Reduction/ } \\
\text { pengurangan }\end{array}$ & 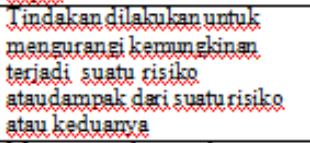 \\
\hline Sharing/gibagitan & $\begin{array}{l}\text { Mengurangi kemungkinan } \\
\text { terjadinya risike dengan } \\
\text { membagi porsi risiko tersebut }\end{array}$ \\
\hline Acceptance / menerimg & $\begin{array}{l}\text { Tidak ada tindgkan yang } \\
\text { dilakukan yntukmengurangi } \\
\text { kemungkinan terjadinyarisiko } \\
\text { atau dampak risiko }\end{array}$ \\
\hline
\end{tabular}

\section{Sumber: Olahan Penulis}

Kemudian penulis akan menjabarkan risiko, dampak, dan alasan berdasarkan apa penulis menetapkan dampak risiko tersebut dari masing-masing tujuan.
Tujuan 1. Aktivitas penjualan sudah dilakukan dengan baik.

Berikut ini merupakan tabel inherent risk yang terdapat pada tujuan 1 beserta dampak dan alasannya:

Tabel 5

Inherent Risk yang Terdapat Pada Tujuan 1 Beserta Dampak dan

\begin{tabular}{|c|c|c|}
\hline \multicolumn{3}{|c|}{ Alasannya } \\
\hline Kisiko & Dampak & Alasan \\
\hline $\begin{array}{l}\text { Tamu yang sudah } \\
\text { melakukan check-in } \\
\text { tidak terdaftar }\end{array}$ & High & $\begin{array}{l}\text { Kecurangan yang } \\
\text { dilakukan Front } \\
\text { Office dengan tidak } \\
\text { melakukan } \\
\text { pencatatan check-in } \\
\text { akan merugikan } \\
\text { hotel }\end{array}$ \\
\hline $\begin{array}{l}\text { Terdapat standar } \\
\text { operational } \\
\text { procedure untuk } \\
\text { melayani tamu } \\
\text { tetapi tidak } \\
\text { dilaksanakan } \\
\text { dengan baik }\end{array}$ & High & $\begin{array}{l}\text { Kualitas pelayanan } \\
\text { yang burukakan } \\
\text { menyebabkan } \\
\text { kepuasan tamu akan } \\
\text { menurun }\end{array}$ \\
\hline $\begin{array}{l}\text { Front office tidak } \\
\text { bisa menjawab } \\
\text { pertanyaan yang } \\
\text { diajukan tamu } \\
\text { sehubungandengan } \\
\text { prosectur check-in' } \\
\text { check-out tipe } \\
\text { kamar dan fasilitas } \\
\text { hotel }\end{array}$ & Medium & $\begin{array}{l}\text { Front office tidak } \\
\text { dapat menjelaskan } \\
\text { pertanyaan yang } \\
\text { diajukan oleh tamu } \\
\text { mengakibatkan tamu } \\
\text { tidak paham dan } \\
\text { dapat menyebabkan } \\
\text { tamu tidakjadi } \\
\text { menginap di Hotel } \\
\text { Alqueby }\end{array}$ \\
\hline
\end{tabular}

\section{Sumber: Olahan Penulis}

Setelah itu, penulis akan mengidentifikasi frekuensi terjadinya dari risiko tersebut beserta alasan mengapa penulis menetapkan frekuensi tersebut. Berikut ini merupakan tabel frekuensi dari risiko yang mungkin terjadi beserta alasannya: 
Tabel 6

\section{Frekuensi Dari Risiko Yang Terdapat Pada Tujuan 1}

\begin{tabular}{|c|c|c|}
\hline Risiko & Frekuensi & Alasan \\
\hline $\begin{array}{l}\text { Tamu yang sudah } \\
\text { melakukan check-m } \\
\text { tidak terdaftar }\end{array}$ & Low & $\begin{array}{l}\text { Tamu, yang } \\
\text { melakukan check } \\
\text { inpasti terdaftar, } \\
\text { karena proses } \\
\text { pembuatan kunci } \\
\text { kamar elektronil } \\
\text { membutuhkan } \\
\text { Rengrisian data tamn }\end{array}$ \\
\hline $\begin{array}{l}\text { Terdapat standar } \\
\text { operational } \\
\text { procedure untuk } \\
\text { melayani tamu } \\
\text { tetapi tidak } \\
\text { dilaksanakan } \\
\text { dengan baik }\end{array}$ & Low & 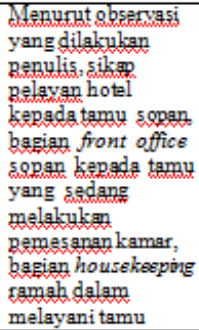 \\
\hline $\begin{array}{l}\text { Front office tidak } \\
\text { bisa menjawab } \\
\text { pertanyaan yang } \\
\text { diajukan tamu } \\
\text { sehubungan dengan } \\
\text { prosedurcheck-in' } \\
\text { check-out tipe } \\
\text { kamar dan fasilitas } \\
\text { hotel }\end{array}$ & Low & 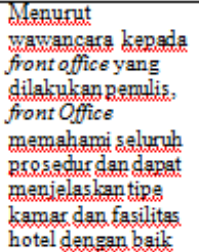 \\
\hline
\end{tabular}

\section{Sumber: Olahan Penulis}

Tujuan 2. Memastikan keluhan tamu ditanggapi dengan cepat dan baik.

Berikut ini merupakan tabel inherent risk yang terdapat pada tujuan 2 beserta dampak dan alasannya:
Tabel 7

Inherent Risk Yang Terdapat Pada Tujuan 2 Beserta Dampak dan

\begin{tabular}{|c|c|c|}
\hline \multicolumn{3}{|c|}{ Alasannya } \\
\hline Risiko & Dampak & Alasan \\
\hline $\begin{array}{l}\text { Front office sulit } \\
\text { dihubungi oleh } \\
\text { tamu via telepon } \\
\text { kamar }\end{array}$ & High & $\begin{array}{l}\text { Front office yang } \\
\text { sulit dihubungi } \\
\text { mengakibatkan } \\
\text { kepuas an tamu } \\
\text { berkurang karena } \\
\text { tidak dapat } \\
\text { menyampaikan } \\
\text { keluhan dengan } \\
\text { cepat }\end{array}$ \\
\hline $\begin{array}{l}\text { Jika tidak ada } \\
\text { keluhan mengenai } \\
\text { fasilitas kamar, } \\
\text { perbaikan tidak } \\
\text { dapat dilakukan } \\
\text { dengan segera }\end{array}$ & High & $\begin{array}{l}\text { Tamu akan merasa } \\
\text { kecewa jika fasilitas } \\
\text { yang rusak tidak } \\
\text { diperbaiki dengan } \\
\text { segera, bahkan jika } \\
\text { tamu sampai } \\
\text { diharuskan pindah } \\
\text { kamar, tamu akan } \\
\text { merasa kerepotan } \\
\text { dalam memindahkan } \\
\text { barang-barang }\end{array}$ \\
\hline
\end{tabular}

\section{Sumber: Olahan Penulis}

Setelah itu, penulis akan mengidentifikasi frekuensi terjadinya dari risiko tersebut beserta alasan mengapa penulis menetapkan frekuensi tersebut. Berikut ini merupakan tabel frekuensi dari risiko yang mungkin terjadi beserta alasannya: 
Tabel 8

Frekuensi Dari Risiko Yang Terdapat Pada Tujuan 2

\begin{tabular}{|c|c|c|}
\hline Risiko & Frekuensi & Alasan \\
\hline $\begin{array}{l}\text { Front office sulit } \\
\text { dihubungi oleh } \\
\text { tamu via telepon } \\
\text { kamar }\end{array}$ & Medium & 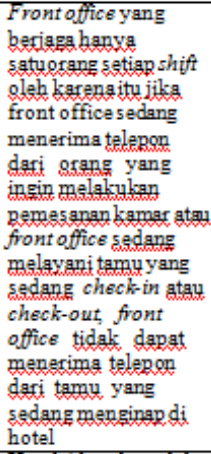 \\
\hline $\begin{array}{l}\text { Jika tidak ada } \\
\text { keluhan mengenai } \\
\text { fasilitas kamar, } \\
\text { perbaikan tidak } \\
\text { dapat dilakukan } \\
\text { dengan segera }\end{array}$ & Medium & $\begin{array}{l}\text { Hotel Alqueby tidak } \\
\text { memiliki pegawai } \\
\text { khusus untuk } \\
\text { perbaikan fasilitas } \\
\text { sehingga hards. } \\
\text { memangsil orang dari } \\
\text { luar untuk } \\
\text { memperbagikj fasilitas } \\
\text { hotel, sehingga } \\
\text { membutuhkan wakts } \\
\text { lama untuk dapat } \\
\text { memperbaiki fasilitas } \\
\text { tersebut }\end{array}$ \\
\hline
\end{tabular}

Sumber: Olahan Penulis

Tujuan 3. Mengoptimalkan fasilitas hotel agar dapat dinikmati oleh tamu.

Berikut ini merupakan tabel inherent risk yang terdapat pada tujuan 3 beserta dampak dan alasannya:

Tabel 9

Inherent Risk Yang Terdapat Pada Tujuan 3 Beserta Dampak dan Alasannya

\begin{tabular}{|c|c|c|}
\hline Risiko & Dampak & Alasan \\
\hline $\begin{array}{l}\text { Fasilitas hotel yang } \\
\text { sudah usang tidak } \\
\text { terdeteksidengan } \\
\text { segera }\end{array}$ & High & $\begin{array}{l}\text { Fasilitas hotel yang } \\
\text { sudah using seperti } \\
\text { besi sudah } \\
\text { berkarat, kasur } \\
\text { sudah tidak nyaman } \\
\text { akan membuat tamu } \\
\text { tidak nyaman ketika } \\
\text { menginap di Hotel } \\
\text { Alqueby dan } \\
\text { dapat menurunkan } \\
\text { reputasi hotel }\end{array}$ \\
\hline $\begin{array}{l}\text { Kebersihan hotel } \\
\text { kurangterjaga }\end{array}$ & $\mathrm{High}$ & $\begin{array}{l}\text { Hotel yang kotor } \\
\text { membuat tamu } \\
\text { tidak nyaman } \\
\text { ketika menginap di } \\
\text { Hotel Alqueby }\end{array}$ \\
\hline
\end{tabular}

Sumber: Olahan Penulis
Setelah itu, penulis akan mengidentifikasi frekuensi terjadinya dari risiko tersebut beserta alasan mengapa penulis menetapkan frekuensi tersebut. Berikut ini merupakan tabel frekuensi dari risiko yang mungkin terjadi beserta alasannya:

Tabel 10

\section{Frekuensi Dari Risiko Yang Terdapat} Pada Tujuan 3

\begin{tabular}{|c|c|c|}
\hline Risiko & Frekuensi & Alasan \\
\hline $\begin{array}{l}\text { Fasilitas hotel yang } \\
\text { sudah usang tidak } \\
\text { terdeteksidengan } \\
\text { segera }\end{array}$ & Low & $\begin{array}{l}\text { Hotel Alquebybaru } \\
\text { berdiri } 3 \text { tahum } \\
\text { sehingga fasilitas } \\
\text { masih tergolong } \\
\text { baru dan memurut } \\
\text { observasi yang } \\
\text { dilakukan perulis, } \\
\text { seluruh fasilitas di } \\
\text { Hotel Alqueby baik } \\
\text { dan tidak terlihat } \\
\text { adanya fasilitas yang } \\
\text { using dan memurut } \\
\text { wawancara dengan } \\
\text { CEO, tidak ada tamu } \\
\text { yang mengeluh } \\
\text { karena fasilitas } \\
\text { pada Hotel Alqueby } \\
\text { sudah usang karana } \\
\text { tidak dirawat denga } \\
\text { baik }\end{array}$ \\
\hline $\begin{array}{l}\text { Kebersihan hotel } \\
\text { kurangterjaga }\end{array}$ & Low & $\begin{array}{l}\text { Menurut observasi, } \\
\text { Hotel Alqueby } \\
\text { sangat } \\
\text { mementingkan } \\
\text { kebersihankarena } \\
\text { tidak ditemukan } \\
\text { sampah/binatang } \\
\text { seperti kecoa di } \\
\text { lorong-lorong hotel } \\
\text { dan di kamar dan } \\
\text { lmenurut CEO, tidak } \\
\text { adanya keluhan } \\
\text { tamu mengenai } \\
\text { kebersihanpada } \\
\text { hotel }\end{array}$ \\
\hline
\end{tabular}

\section{Sumber: Olahan Penulis}

d. Pengendalian/ control yang dilakukan oleh Hotel Alqueby untuk mencegah terjadinya risiko.

Berikut ini merupakan pengendalian yang dilakukan oleh Hotel Alqueby untuk mencegah terjadinya inherent risk yang telah penulis jabarkan sebelumnya: 
Tabel 11

Pengendalian Atas Risiko

\begin{tabular}{|c|c|}
\hline Risiko & Kontrol \\
\hline $\begin{array}{l}\text { Tamu yang sudgh } \\
\text { melakukancheck-in tidak } \\
\text { terdaftar. }\end{array}$ & 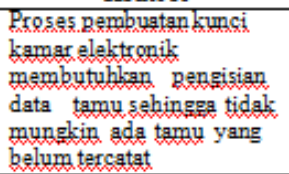 \\
\hline $\begin{array}{l}\text { Terdapat standar operational } \\
\text { procedure untukmelayani. } \\
\text { tamu tetapi tidak. } \\
\text { dilaksanalan dengan baik }\end{array}$ & 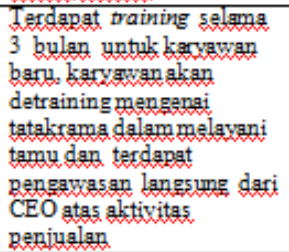 \\
\hline $\begin{array}{l}\text { Front office tidak bisa } \\
\text { menjawab, pertanvagn yang } \\
\text { diajukan tamu sehuburgan } \\
\text { dengan prosedur check-in } \\
\text { check-out, tipe bamar dan } \\
\text { fasilitas hotel }\end{array}$ & $\begin{array}{l}\text { Terdapat intensive training } \\
\text { untuk barygwan baru selama } \\
3 \text { mingar sehingra front } \\
\text { office pasti memahami. } \\
\text { prosedur dengan baik }\end{array}$ \\
\hline $\begin{array}{l}\text { Front office sulit dihubungi } \\
\text { sleh tamu via teleponksmer }\end{array}$ & $\begin{array}{l}\text { Front office ditambah } \\
\text { menjadidua orang betika } \\
\text { alkir pelan }\end{array}$ \\
\hline $\begin{array}{l}\text { Tamu tidak dapgt terlavani } \\
\text { seluruhnua dengan cepgt }\end{array}$ & $\begin{array}{l}\text { Menampahjum a h staff } \\
\text { pada hari raya }\end{array}$ \\
\hline 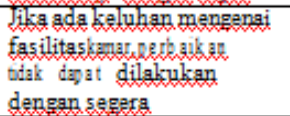 & 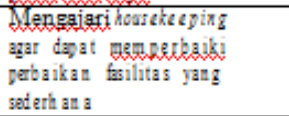 \\
\hline $\begin{array}{l}\text { Fasilitas hotel yang sudah } \\
\text { usangtidakterdeteksi. } \\
\text { dengan segara. }\end{array}$ & $\begin{array}{l}\text { Public coordinator dan } \\
\text { Housekesping leader setiap } \\
\text { pagi melakulan pengecelsan } \\
\text { kepada fasilitas hotel }\end{array}$ \\
\hline $\begin{array}{l}\text { Kebersihan hotel kurang } \\
\text { teriags }\end{array}$ & $\begin{array}{l}\text { Public coordinator dan } \\
\text { Housekeeping leader setiap } \\
\text { pagi melakulan pengegel } \\
\text { terhadap kebersihan hotel }\end{array}$ \\
\hline
\end{tabular}

Sumber: Olahan Penulis

\section{Flowchart}

Flowchart adalah adalah suatu bagan dengan simbol-simbol tertentu yang menggambarkan urutan proses secara mendetail dan hubungan antara suatu proses (instruksi) dengan proses lainnya dalam suatu program. Flowchart penjualan hotel merupakan bagan yang menggambarkan proses dari reservasi yang dilakukan oleh tamu hingga proses check-out berlangsung. Penulis akan membahas flowchart penjualan Hotel Alqueby beserta pengendalian internal yang terdapat dalam proses sehingga penulis dapat menyimpulkan apakah pengendalian internal yang sudah ada telah memadai dan apakah pengendalian internal yang sudah ada telah dilaksanakan dengan baik.
Hotel Alqueby belum mempunyai flowchart, sehingga penulis membuat flowchart aktivitas penjualan Hotel Alqueby berdasarkan prosedur penjualan dan wawancara yang penulis lakukan dengan CEO Hotel Alqueby. Aktivitas penjualan pada Hotel Alqueby dibagi menjadi 3 yaitu reservasi, check-in dan penerimaan pembayaran, check-out. Reservasi dapat dilakukan melalui telepon, datang langsung ke hotel, dan melalui online travel agent.

Pengendalian yang Terdapat Dalam Aktivitas Penjualan Hotel Alqueby

Terdapat beberapa pengendalian dalam aktivitas penjualan Hotel Alqueby yaitu:

a. Hanya front office yang dapat mengakses komputer dan terdapat password pada komputer front office sehingga orang yang tidak berkepentingan tidak akan dapat mengubah atau menghapus data.

b. Tamu yang melakukan reservasi akan dicatat pada data ketersediaan kamar oleh front office, sehingga tidak akan terjadi double booking pada kamar.

c. Invoice dan bukti pembayaran rangkap dua diberikan kepada CEO selaku accounting. Hal ini merupakan pengendalian tidak langsung atas aktivitas pembayaran tagihan kamar.

d. Ketika check-out, housekeeping mengecek apakah ada barang yang rusak atau tidak, sehingga kerugian akibat kerusakan fasilitas yang disebabkan oleh tamu tidak ditanggung hotel.

e. Terdapat kebijakan pembayaran DP untuk resevasi, sehingga hotel tidak akan menanggung kerugian yang terlalu besar bila terdapat tamu yang melakukan pembatalan atas reservasi. Jika terdapat tamu yang tidak membayar DP, maka reservasi akan dibatalkan dengan sendirinya, sehingga hotel dapat menyewakan kamar tersebut kepada tamu lain. 
f. Kunci kamar merupakan kunci elektronik dan saat pembuatan kunci elektronik tersebut front office harus mengisi data tamu pada program kunci elektronik sehingga mengurangi risiko penjualan ilegal oleh front office.

\section{Kekurangan yang Terdapat Dalam Aktivitas Penjualan}

Berdasarkan flowchart Hotel Alqueby, penulis menemukan beberapa kekurangan yang terdapat pada aktivitas penjualan Hotel Alqueby, yaitu:

a. Tidak ada pemisahan fungsi pada bagian front office. Front office yang bertugas untuk reservasi, menghitung jumlah tagihan, dan menerima pembayaran merupakan orang yang sama. Hal ini dapat menimbulkan kecurangan.

b. Pengawasan terhadap aktivitas penjualan dilakukan oleh CEO Hotel Alqueby, maka pengawasan kurang efektif sebab CEO tidak berada di lokasi setiap saat.

c. Meskipun kunci kamar sudah merupakan kunci elektronik dan terdapat pencatatan data tamu pada program kunci elektronik, belum ada audit yang dilakukan oleh Hotel Alqueby atas pencocokan data tamu pada program kunci elektronik dan data tamu pada program check-in. Sehingga apabila front office tidak mencatat data tamu pada program check-in dan tidak menerbitkan invoice, hanya mencatat data tamu pada program kunci elektronik saja tidak akan terdeteksi sehingga peluang terjadinya penjualan ilegal tetap ada.

d. Tidak terdapat kebijakan menyimpan deposit pada saat check-in menyebabkan tidak ada jaminan bila tamu tidak mau membayar denda karena merusak fasilitas hotel.

\section{Field Work Phase (Tahap Penelitian Lapangan)}

Pada tahap pemeriksaan lapangan ini penulis akan menerapkan langkah-langkah yang telah dibuat pada tahap program kerja agar penulis dapat lebih memahami kegiatan penjualan pada Hotel Alqueby dan mengidentifikasi area yang memiliki kelemahan sehingga penulis dapat memberikan rekomendasi yang sesuai untuk mengatasi kelemahan tersebut.

\section{Mengevaluasi Pelaksanaan Pengendalian Internal Hotel Alqueby}

Pembuatan pengendalian internal yang baik tidak akan efektif bila pengendalian internal tersebut tidak dilaksanakan dengan baik. Untuk mengetahui apakah pengendalian internal telah dilaksanakan atau belum sesuai yang seharusnya, maka penulis membuat kuesioner pengendalian internal. Kuesioner ini diedarkan kepada karyawan front office, staff cafe, dan public coordinator.

Berdasarkan hasil kuesioner pengendalian internal, dapat disimpulkan bahwa pengendalian internal Alqueby sudah dilaksanakan dengan baik, ditunjukan dengan:

a. KTP tamu selalu difotocopy oleh bagian front office saat check-in.

b. Selalu terdapat supervisor yang mengawasi karyawan, yaitu front office diawasi oleh CEO, sedangkan housekeeping diawasi oleh hotel public coordinator.

c. Bukti pembayaran bagi tamu yang telah melakukan DP selalu dikirim kepada tamu oleh front office melalui email.

d. Check-in tidak akan diproses bila tamu tidak mau melakukan pembayaran saat check-in.

e. Bika terdapat kerusakan pada fasilitas kamar, denda akan dikenakan sesuai dengan jumlah kerusakan.

f. Pada saat tamu check-out, selalu dilakukan pengecekan kamar oleh housekeeping. 
g. Tamu wajib mengembalikan kunci kamar kepada front office saat checkout.

h. Front office selalu melaporkan laporan penjualan setiap hari kepada CEO.

i. Uang hasil penjualan disimpan di tempat khusus oleh front office untuk mencegah kecurian.

j. Terdapat password pada komputer front office dan hanya front office yang mengetahui password tersebut sehingga tidak sembarangan orang dapat mengakses komputer front office.

k. Penomoran dokumen sudah dilakukan dengan baik.

1. Hanya karyawan yang mempunyai otoritas dapat mengakses dokumen.

m. Bagian kitchen setiap pagi mengirim sample makanan ke manajemen sehingga kualitas rasa terjamin untuk menu breakfast.

n. Tamu yang sudah breakfast akan dicatat pada breakfast list.

o. Terdapat slip order jika tamu memesan makanan di cafe.

p. Training selalu dilakukan pada 3 minggu pertama pegawai baru bekerja.

q. Struktur organisasi dan job description sudah disampaikan dan dimengerti oleh karyawan.

r. Terdapat evaluasi mengenai hasil penjualan tiap bulan.

s. Setiap karyawan selalu memberikan dokumen daily work flow kepada public coordinator dan dokumen tersebut akan diperiksa oleh public coordinator.

t. Public coordinator tidak melakukan pengecekan setiap pagi, hanya tiga hari sekali.

Terdapat beberapa pelanggaran terhadap pengendalian internal, diantaranya adalah:

a. Briefing tidak dilakukan setiap hari, terutama pada shift malam, briefing sering tidak dilakukan.

b. Public coordinator tidak setiap pagi melakukan pengecekan terhadap kebersihan hotel. c. Public coordinator tidak setiap pagi melakukan pengecekan terhadap fasilitas hotel.

\section{Analisis Target Penjualan Dengan Penjualan Aktual Pada Hotel Alqueby Dari Tahun 2015 Hingga 2016}

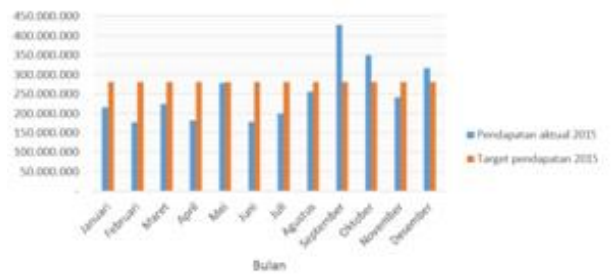

Gambar 1

Diagram Batang Perbandingan

Pendapatan Aktual dan Target

Pendapatan Hotel

Tahun 2015

Sumber: Olahan penulis

Berdasarkan diagram diatas dapat dilihat bahwa penjualan pada Hotel Alqueby berfluktuasi. Pada tahun 2015 Hotel Alqueby hanya mencapai target penjualan sebanyak tiga kali, yaitu pada bulan September, Oktober, dan Desember. Pada bulan September Hotel Alqueby berhasil mencapai target penjualannya sebesar $1.13 \%$, pada bulan Oktober Hotel Alqueby berhasil mencapai target penjualannya sebesar $24.75 \%$, sedangkan pada bulan Desember Hotel Alqueby mencapai target penjualannya sebesar $12.88 \%$. Pada bulan Mei Hotel Alqueby hampir mencapai target penjualan. Penjualan tertinggi terjadi pada bulan September. Menurut wawancara yang penulis lakukan dengan sales and marketing executive, pada bulan September 2015 terdapat lonjakan penjualan kamar hotel karena adanya event POMNAS (Pekan Olahraga Pelajar Nasional) yang diadakan pada tanggal 10-21 September 2015 di Kota Bandung dan peserta POMNAS memilih Hotel Alqueby sebagai tempat menginap selama berada di Bandung. Pada bulan Oktober terdapat 
reservasi grup untuk rombongan yang akan berkeliling di Bandung dan berwisata ke Trans Studio Bandung. Sedangkan pada bulan Desember merupakan high season sehingga penjualan meningkat.

Dilihat dari banyaknya varians negatif, target penjualan yang telah ditetapkan dinilai kurang tepat karena target penjualan dibuat sama setiap bulan dan tidak memperhitungkan bulan-bulan high season dan bulan-bulan low season. Seharusnya, target penjualan tidak dibuat konstan setiap bulan.

Selain itu, rendahnya penjualan pada hotel dapat diakibatkan karena kurangnya pengetahuan tamu atas Hotel Alqueby. Menurut wawancara yang penulis lakukan dengan front office, banyak tamu yang mengaku mengetahui keberadaan Hotel Alqueby karena memiliki kerabat yang tinggal di daerah Antapani dekat Hotel Alqueby. Hotel Alqueby baru berdiri pada tahun 2013 dan promosi harus dilakukan untuk meningkatkan brand awareness.

Promosi yang dilakukan Hotel Alqueby kurang optimal. Promosi yang kurang optimal ini diakibatkan karena tidak terdapat staf pemasaran, sehingga pemasaran hanya dilakukan oleh direktur dan sales and marketing executive. Pada tahun 2015, promosi hanya dilakukan dengan melalui media sosial dan direktur Alqueby beserta sales and marketing executive mengikuti pameran hotel pada bulan Maret dan November. Pameran pada bulan Maret dianggap tidak efektif karena tidak berdampak terhadap peningkatan penjualan pada bulan berikutnya. Sedangkan pameran pada bulan November cukup efektif karena terdapat peningkatan penjualan pada bulan Desember.

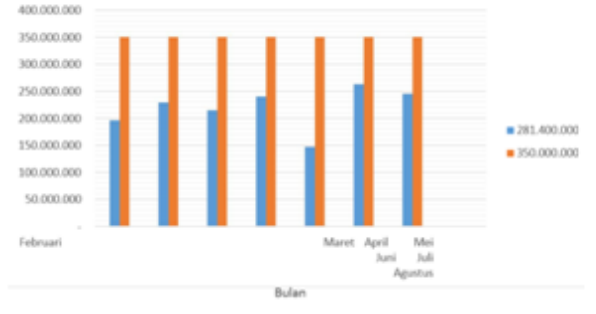

Gambar 2

Diagram Batang Perbandingan Pendapatan Aktual dan Target Pendapatan Hotel Tahun 2016 Sumber: Olahan Penulis

Berdasarkan diagram diatas dapat disimpulkan bahwa selama bulan Januari 2016 hingga Agustus 2016, Hotel Alqueby belum pernah mencapat target pendapatan. Pendapatan terendah terjadi pada bulan Juni dengan total pendapatan 146.300.000 dan varians unfavourable sebesar $58.20 \%$ sedangkan pendapatan tertinggi terjadi pada bulan Januari dengan total pendapatan 281.400 .000 dan varians unfavourable sebesar $19.60 \%$. Sehingga dapat ditarik kesimpulan bahwa pada tahun 2016, pembuatan target penjualan belum baik karena masih tidak memperhitungkan low season dan high season. Sebaiknya, target penjualan tidak dibuat konstan setiapbulan tetapi memperhitungkan low season dan high season. Penjualan yang rendah juga dapat diakibatkan karena kurangnya promosi yang dilakukan. Selama bulan Januari hingga Agustus 2016, promosi dilakukan hanya dengan melalui media sosial dan direktur mengikuti pameran hotel pada bulan Januari.

Berikut ini merupakan perbandingan antara pendapatan aktual hotel pada tahun 2015 dengan tahun 2016: 


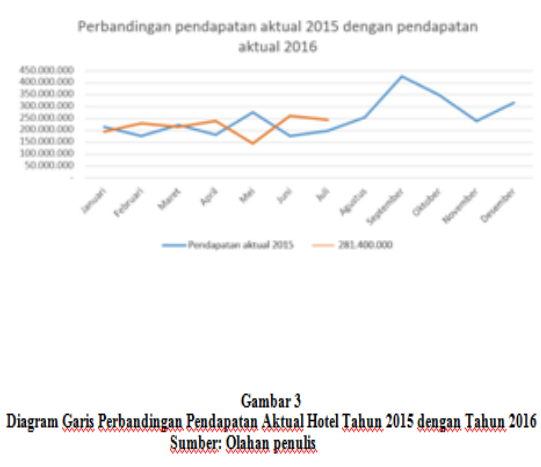

Dapat dilihat bahwa penjualan berfluktuasi. Pendapatan pada tahun 2016 lebih tinggi daripada tahun 2015 pada bulan Januari, Februari, Maret, April dan Juli. Sedangkan pada bulan Mei dan Agustus pedapatan pada tahun 2016 lebih rendah daripada tahun 2015 .

\section{Development of Review Findings and Recommendation Phase (Tahap Pengembangan Temuan dan Rekomendasi)}

Pada tahap ini penulis menjabarkan temuan-temuan yang didapat selama proses field work dan penulis akan menganalisis dan memberikan rekomendasi yang sesuai. Berikut ini adalah temuan-temuan yang penulis peroleh:

a. Tidak ada pemisahan fungsi pada bagian front office. Front office yang bertugas untuk reservasi, menghitung jumlah tagihan, dan menerima pembayaran merupakan orang yang sama. Hal ini dapat menimbulkan kecurangan.

b. Pengawasan pada front office dilakukan oleh CEO sehingga tidak berjalan dengan optimal karena CEO tidak berada di lokasi setiap saat.

c. Training dilakukan oleh $\mathrm{CEO}$, hal ini juga tidak dapat berjalan dengan optimal karena CEO banyak pekerjaan yang harus ditanggung oleh CEO, seperti accounting dan pengawasan front office. d. Tidak adanya kebijakan diskon pada pelangan tetap, padahal hal ini dapat memicu agar tamu berlangganan menginap di Hotel Alqueby.

e. Tidak adanya staff marketing, sehingga kegiatan marketing dilakukan oleh sales and marketing executive dan direktur.

f. Tidak ada kebijakan mengenai aktivitas marketing.

g. Tidak ada penyusunan anggaran biaya marketing.

h. Kegiatan marketing kurang optimal, hanya dilakukan melalui pameran di berbagai kota oleh direktur dan sales and marketing executive.

i. Tidak ada pemberian bonus pada sales and marketing executive sehingga dapat mengakibatkan kurangnya motivasi untuk mencapai target penjualan hotel.

j. Public coordinator dan housekeeping leader tidak setiap pagi melakukan pengecekan terhadap kebersihan hotel.

k. Briefing tidak dilakukan setiap hari,

1. terutama pada shift malam, briefing sering tidak dilakukan.

m. Dokumen masih diisi secara manual sehingga memakan waktu lebih lama dan kurang efektif karena front office harus bekerja dua kali, yaitu mengisi dokumen manual dan juga mengisi pada program di komputer.

n. Pihak front office tidak melakukan pencatatan pada komputer untuk reservasi, front office hanya mengupdate pada data ketersediaan kamar tanpa melakukan pencatatan mengenai data diri tamu yang menginap. Jika suatu saat terjadi hal yang tidak diinginkan seperti semua dokumen hilang, maka data mengenai reservasi hilang semua karena tidak memiliki back up.

o. Ruang tunggu lobi terbatas hanya memiliki dua kursi sehingga tamu mengeluh ketika menunggu untuk melakukan reservasi/ check-in / checkout.

p. Cafe hanya memiliki tujuh meja dan meja tambahan disimpan diluar cafe 
sehingga menyulitkan staff cafe untuk mengecek voucher breakfast dan data masing-masing tamu ketika breakfast karena banyak tamu yang keluar masuk cafe untuk mengambil makanan. Pengecekan voucher breakfast dilakukan di depan cafe.

q. Tidak terdapat kebijakan menyimpan deposit pada saat check-in.

r. Target penjualan tidak dibuat dengan baik.

Analisis 1 berkaitan dengan adanya pekerjaan rangkap pada struktur organisasi Hotel Alqueby

Temuan:

a. Tidak ada pemisahan fungsi pada bagian front office. Front office yang bertugas untuk reservasi, menghitung jumlah tagihan, dan menerima pembayaran merupakan orang yang sama. Hal ini dapat menimbulkan kecurangan.

b. Pengawasan pada front office dilakukan oleh CEO sehingga tidak berjalan dengan optimal karena CEO tidak berada di lokasi setiap saat.

c. Training dilakukan oleh CEO, hal ini juga tidak dapat berjalan dengan optimal karena CEO banyak pekerjaan yang harus ditanggung oleh CEO, seperti accounting dan pengawasan front office.

1) Kondisi

Front office tidak dipisahkan fungsinya menjadi resepsionis, kasir, dan pencatatan. CEO merangkap menjadi accounting, supervisor front office, dan human resource department.

2) Kriteria

Seharusnya terdapat pemisahan fungsi antara karyawan yang bertugas untuk melakukan pencatatan dan karyawan yang dapat menangani aset secara fisik. Sebaiknya satu pekerjaan dikerjakan oleh satu bagian sehingga pekerjaan tidak menumpuk.
3) Penyebab

Struktur organisasi Hotel Alqueby masih sangat sederhana. Karyawan yang bekerja juga tidak banyak karena Hotel Alqueby merupakan hotel budget sehingga karyawan sedikit untuk mengurangi biaya. Hal ini mengakibatkan banyaknya pekerjaan rangkap yang dilakukan oleh karyawan.

4) Dampak

Dapat terjadi kecurangan atau penjualan kamar ilegal dilakukan oleh frontoffice dengan cara menjual kamar tanpa mengisi data registrasi pada program dikomputer dan pada dokumen registrasi lalu memberikan invoice palsu pada customer. CEO yang mengerjakan banyak pekerjaan menjadi tidak fokus dengan pekerjaan utamanya yaitu menyusun strategi untuk mengembangkan Hotel Alqueby.

5) Rekomendasi

Karena Hotel Alqueby merupakan hotel budget dimana manajer harus berusaha untuk meminimalisir biaya, maka penambahan pegawai bukan pilihan yang baik bagi pemecahan masalah segregation of duties ini. Penulis menyarankan CEO untuk membagi tugas dengan direktur seperti direktur merangkap sebagai accounting, CEO sebagai human resource department untuk perekrutan pegawai baru dan supervisor front office. Sedangkan untuk training pegawai baru, penulis menyarankan agar CEO mengajarkan pegawai yang sudah senior sehingga pegawai tersebut dapat melakukan training terhadap pegawai baru.

Sedangkan untuk mengatasi front office yang merangkap menjadi resepsionis, kasir, dan pencatatan, penulis menyarankan agar CEO melakukan pengecekan setiap hari antara data kunci elektronik yang dibuat melalui program Hune dengan data check-in 
yang diinput pada program komputer. Sebaiknya program komputer check-in dibuat terintegrasi dengan komputer CEO sehingga CEO dapat dengan mudah melakukan pengecekan. Bila terdapat data yaitu kunci dibuat tetapi tidak ditemukan pada data check-in pada program komputer, maka telah terjadi penjualan ilegal yang dilakukan oleh front office.

Analisis 2 berkaitan dengan marketing Hotel Alqueby.Temuan:

d. Tidak adanya kebijakan diskon pada pelangan tetap, padahal hal ini dapat memicu agar tamu berlangganan menginap di Hotel Alqueby.

e. Tidak adanya staff marketing, sehingga kegiatan marketing dilakukan oleh sales and marketing executive dan direktur.

f. Tidak ada kebijakan mengenai aktivitas marketing.

g. Tidak ada penyusunan anggaran biaya marketing.

h. Kegiatan marketing kurang optimal, hanya dilakukan melalui pameran di berbagai kota oleh direktur dan sales and marketing executive.

i. Tidak ada pemberian bonus pada sales and marketing executive sehingga dapat mengakibatkan kurangnya motivasi untuk mencapai target penjualan hotel.

1) Kondisi

Hotel Alqueby tidak mempunyai staff marketing dan kegiatan pemasaran kurang optimal karena hanya dilakukan melalui pameran hotel di berbagai kota yang diikuti oleh direktur dan sales and marketing executive. Hotel Alqueby juga tidak pernah menyusun strategi pemasaran.

2) Kriteria

Sebaiknya setiap perusahaan mempunyai divisi pemasaran dan menyusun strategi pemasaran karena pemasaran merupakan aktivitas yang penting dan sangat berpengaruh bagi penjualan.
3) Penyebab

Staff pemasaran yang sebelumnya keluar dan belum dicarikan penggantinya.Tetapi meskipun Hotel Alqueby pernah memiliki staff pemasaran, kegiatan pemasaran pada saat itu kurang efektif karena divisi pemasaran tidak pernah menyusun strategi pemasaran dan menyusun anggaran pemasaran.

4) Dampak

Promosi tidak dilakukan secara maksimal sehingga tidak terjadi peningkatan pada penjualan kamar Hotel Alqueby.

5) Rekomendasi

Sebaiknya Hotel Alqueby melakukan perekrutan untuk staff divisi pemasaran sehingga kegiatan pemasaran dapat ditingkatkan misalnya melalui iklan di radio, brosur, spanduk dan sebaiknya Hotel Alqueby menyusun strategi pemasaran dan meyusun anggaran.

Analisis 3 terkait dengan pencatatan dokumen

Temuan:

j. Dokumen masih diisi secara manual sehingga memakan waktu lebih lama dan kurang efektif karena front office harus bekerja dua kali, yaitu mengisi dokumen manual dan juga mengisi pada program di komputer.

k. Pihak front office tidak melakukan pencatatan pada komputer untuk reservasi, front office hanya mengupdate pada data ketersediaan kamar tanpa melakukan pencatatan mengenai data diri tamu yang menginap. Jika suatu saat terjadi hal yang tidak diinginkan seperti semua dokumen hilang, maka data mengenai reservasi hilang semua karena tidak memiliki back up.

1) Kondisi

Ditemukan bahwa dokumen masih diisi secara manual dan tidak terdapat pencatatan untuk data reservasi pada program komputer. 
2) Kriteria

Terdapat pencatatan untuk data reservasi pada program komputer dan dokumen dicetak berdasarkan data yang diinput kepada program komputer.

3) Penyebab

Hal ini diakibatkan karena keterbatasan program komputer, pembuatan program kurang efektif.

4) Dampak

Front office harus melakukan pekerjaan dua kali, yaitu harus mengisi dokumen secara manual kemudian mengisi data pada program komputer. Hal ini mengakibatkan pekerjaan menjadi lebih lama. Data reservasi yang tidak diinput pada komputer akan menyebabkan data bisa hilang jika dokumen rusak/hilang karena dokumen fisik sangat rentan akan kerusakan atau kehilangan, dan juga pencarian dokumen fisik memakan waktu yang lebih lama daripada mencari data pada komputer.

5) Rekomendasi

Sebaiknya Hotel Alqueby meningkatkan programnya. Sebaiknya formulir registrasi, bukti pembayaran dicetak melalui program. Sehingga, ketika front office selesai menginput data tamu pada program komputer, front office tidak perlu mengisi formulir registrasi lagi tetapi cukup melakukan print. Data reservasi juga sebaiknya diinput kedalam program komputer sehingga front office menjadi lebih mudah ketika melakukan pengecekan data reservasi tamu ketika tamu yang sudah melakukan reservasi melakukan check-in dan tidak ada risiko hilang dokumen jika sudah diinput ke dalam komputer karena semua data dalam komputer memiliki back-up.

Analis empat terkait dengan pelanggaran pelaksanaan pengendalian internal.

Temuan:

1. Public coordinator tidak setiap pagi melakukan pengecekan terhadap kebersihan hotel.

m. Briefing tidak dilakukan setiap hari, terutama pada shift malam, briefing sering tidak dilakukan.

n. Public coordinator tidak setiap pagi melakukan pengecekan terhadap fasilitas hotel.

1) Kondisi

Terdapat pelanggaran pada pelaksanaan pengendalian internal.

2) Kriteria

Seharusnya pengendalian internal dilaksanakan dengan baik. Public coordinator dan housekeeping leader seharusnya setiap pagi melakukan pengecekan terhadap kebersihan hotel dan briefing seharusnya dilakukan setiap hari setiap pergantian shift.

3) Penyebab

Hal ini disebabkan oleh kelalaian pegawai dalam melaksanakan tugasnya.

4) Dampak

Kebersihan hotel merupakan hal yang penting sehingga jika public coordinator tidak setiap pagi melakukan pengecekan terhadap kebersihan hotel dan petugas housekeeping lalai dalam menjalankan tugasnya, kebersihan hotel tidak terjamin dan tidak dapat terdeteksi bila housekeeper tidak jujur dalam mengisi daily workflow bila tidak dilakukan pengecekan secara rutin. Public coordinator tidak setiap pagi melakukan pengecekan terhadap fasilitas hotel menyebabkan fasilitas yang rusak tidak terdeteksi. Hotel Alqueby tidak mempunyai petugas khusus untuk perbaikan fasilitas sehingga fasilitas 
yang rusak tidak dapat diperbaiki dengan segera karena harus mendatangkan petugas dari luar, sehingga pengecekan atas fasilitas hotel wajib dilakukan agar dapat diperbaiki sebelum tamu menginap. Briefing penting untuk dilakukan agar pegawai tahu kondisi pada hari itu.

5) Rekomendasi

Pegawai harus mengerjakan tugasnya sesuai dengan prosedur yang berlaku dan setiap pegawai harus melaporkan hasil pekerjaannya kepada CEO setiap hari sehingga CEO akan mengetahui bila terdapat pelanggaran prosedur.

Analis 5 terkait dengan keterbatasan fasilitas hotel.

Temuan:

o. Ruang tunggu lobi hanya memiliki dua kursi sehingga tamu mengeluh ketika menunggu untuk melakukan reservasi/ check-in/check-out.

p. Cafe hanya memiliki tujuh meja dan meja tambahan disimpan diluar cafe sehingga menyulitkan staff cafe untuk mengecek voucher breakfast dan data masing-masing tamu ketika breakfast karena banyak tamu yang keluar masuk cafe untuk mengambil makanan. Pengecekan voucher breakfast dilakukan didepan cafe.

1) Kondisi

Ruang tunggu lobi hanya memiliki dua kursi dan cafe hanya memiliki tujuh meja.

2) Kriteria

Seharusnya kursi pada ruang tunggu lobi diperbanyak agar tamu dapat beristirahat ketika menunggu akan reservasi, check-in atau check-out. Seharusnya staff cafe dapat mengontrol tamu yang keluar masuk cafe saat breakfast.

3) Penyebab

Keterbatasan lahan menyebabkan cafe dibuat kecil.
4) Dampak

Kepuasan tamu berkurang ketika tamu seharusnya menunggu lama saat akan reservasi, check-in atau check-out. Cafe yang hanya memiliki tujuh meja akan menyulitkan staff cafe untuk mengecek voucher breakfast dan data masing-masing tamu ketika breakfast karena meja tambahan diletakan di luar cafe sehingga banyak tamu yang keluar masuk cafe untuk mengambil makanan. Pengecekan voucher breakfast dilakukan di depan cafe. Hal ini dapat menimbulkan tamu yang tidak memiliki voucher breakfast memanfaatkan kesempatan ini untuk mendapatkan breakfast secara gratis.

5) Rekomendasi

Penulis menyarankan agar kursi pada ruang tunggu lobi ditambah sehingga tamu dapat duduk ketika menunggu melakukan checkin.Sebaiknya breakfast dibagi-bagi perlantai karena masih terdapat lahan kosong pada lantai dua dan tiga cukup untuk tempat kursi dan meja untuk breakfast. Sehingga tamu yang menginap di lantai satu akan mengambil breakfast di lantai satu, tamu yang menginap di lantai dua akan mengambil breakfast di lantai dua, dan tamu yang menginap di lantai tiga akan mengambil breakfast di lantai tiga. Sehingga dengan pembagian seperti ini, tamu tidak perlu mengambil breakfast di ruang tambahan dan keluar masuk cafe untuk menambah makanan, tamu yang masuk ke ruang breakfast akan dapat dengan mudah dikontrol oleh penjaga ruang breakfast. 
Analisis 6 terkait dengan kebijakan deposit saat check-in.

Temuan:

q. Tidak terdapat kebijakan menyimpan deposit pada saat check in.

1) Kondisi

Tidak terdapat kebijakan menyimpan uang deposit pada saat tamu melakukan check-in.

2) Kriteria

Sebaiknya terdapat kebijakan menyimpan uang deposit pada saat tamu check-in sebagai jaminan bila tamu tidak mau membayar denda ketika terjadi kerusakan pada fasilitas hotel yang disebabkan oleh tamu.

3) Penyebab

Tidak dibuat kebijakan mengenai penyimpanan uang deposit.

4) Dampak

Bila tamu merusak fasilitas hotel dan tidak mau membayar denda maka hotel tidak mempunyai jaminan.

5) Rekomendasi

Sebaiknya dibuat kebijakan mengenai pembayaran uang deposit sebesar Rp100.000 ketika tamu melakukan check-in.

Analisis 7 terkait dengan penetapan target penjualan yang kurang baik.

Temuan:

r. Target penjualan tidak dibuat dengan baik.

1) Kondisi

Target penjualan dibuat konstan setiap bulan, tidak memperhitungkan kondisi low season atau high season, sehingga pada bulan low season, target terlalu tinggi untuk dicapai.

2) Kriteria

Seharusnya target penjualan dibuat dengan memperhitungkan berbagai faktor yang ada.
3) Penyebab

Target penjualan tidak memperhitungkan faktor low season atau high season.

4) Dampak

Target penjualan terlalu tinggi dan sulit untuk dicapai sehingga terdapat banyak varians negatif karena penjualan aktual tidak dapat mencapai target penjualan, target penjualan yang terlalu tinggi juga menurunkan motivasi karyawan dalam pencapaian target karena dianggap tidak realistis untuk dicapai.

5) Rekomendasi

Sebaiknya dibuat target penjualan baru dengan lebih memperhitungkan faktor low season dan high season.

\section{Simpulan dan Saran}

\section{Simpulan}

Berdasarkan pemeriksaan operasional yang penulis lakukan atas aktivitas penjualan Hotel Alqueby, penulis dapat menarik kesimpulan sebagai berikut:

1. Siklus pendapatan/aktivitas penjualan pada Hotel Alqueby dapat dibagi menjadi 4 yaitu penerimaan pesanan tamu, pendaftaran tamu (check-in) dan penerimaan pembayaran, check-out. Keempat aktivitas penjualan ini dilakukan oleh front office. Aktivitas penjualan dimulai dengan adanya penerimaan pesanan tamu. Penerimaan pesanan tamu atau reservasi dapat dilakukan dengan cara datang langsung ke Hotel Alqueby, via telepon, atau via online travel agent. Data mengenai reservasi tamu akan dicatat pada formulir reservasi. Jika tamu melakukan reservasi maka tamu diwajibkan untuk membayar uang muka maksimal h-1 sebelum menginap, bila tidak maka reservasi akan dibatalkan pada h-1. Bagi tamu yang melakukan reservasi via online travel agent maka tamu harus 
melunasi tagihan kamar pada saat resevasi melalui transfer. Kemudian setelah reservasi, akan dilakukan checkin. Tamu diharuskan untuk melunasi pembayaran saat check-in. Pada saat check-in, front office akan menginput data tamu ke dalam program komputer dan akan mengisi formulir registrasi dan membuat bukti pembayaran jika tamu telah melunasi tagihan. Front office memfotocopy KTP milik tamu dan menempelkannya pada formulir registrasi. Front office juga membuat kunci elektronik dan memberikan voucher breakfast untuk tamu. Aktivitas yang terakhir pada siklus pendapatan Hotel Alqueby adalah saat check-out. Tamu yang melakukan check-out akan mengembalikan kartu elektronik kepada front office dan front office memberikan invoice kepada tamu. Jumlah yang tertera pada invoice sama seperti jumlah yang tertera pada bukti pembayaran jika tamu tidak dikenakan denda. Denda berlaku bila tamu merusak fasilitas kamar. Selain dari penjualan kamar, Hotel Alqueby juga mendapatkan keuntungan dari cafe. Pengunjung yang tidak menginap di Hotel Alqueby juga dapat membeli makanan di cafe. Pembayaran makanan cafe untuk tamu hotel maupun untuk bukan tamu harus dibayar langsung pada saat tamu selesai makan dan meninggalkan cafe. Penulis menemukan beberapa kelemahan pada siklus pendapatan ini, yaitu tidak adanya pemisahan fungsi pada bagian reservasi, penerimaan pembayaran, dan pencatatan pada front office. Selain itu juga pengisian dokumen kecuali invoice masih secara manual sehingga kurang efektif karena front office harus mengerjakan dua kali yaitu saat menulis dokumen manual dan menginput data ke komputer. Formulir reservasi tidak diinput ke komputer sehingga tidak ada back-up jika formulir hilang dan kurang efektif karena menyulitkan front office ketika mencocokan data reservasi pada saat tamu datang untuk check-in karena dokumen fisik lebih sulit dicari daripada dokumen pada komputer.

2. Penulis melakukan analisis nonkeuangan pada Hotel Alqueby yaitu dengan membuat risk and control matrix untuk mengetahui inherent risk dan pengendalian yang dilakukan untuk mencegah terjadinya inherent risk tersebut. Penulis juga melakukan walkthorugh dan analisis dokumen yang digunakan untuk dapat mengetahui apakah dokumen yang digunakan sudah dirancang dengan baik, diberi penomoran, disimpan, dan diotorisasi dengan baik. Kemudian penulis mengevaluasi siklus pendapatan beserta prosedur yang berlaku sehingga dapat mengetahui kelemahan apa yang terdapat pada siklus mendapatan. Selain itu juga penulis melakukan wawancara dengan pihak yang berkaitan dengan aktivitas penjualan agar dapat mengetahui kesulitan yang terjadi dalam melaksanakan aktivitas penjualan dan terakhir penulis mengevaluasi pelaksanaan pengendalian internal untuk memastikan bahwa pegawai sudah melaksanakan pengendalian internal dengan baik. Penulis melakukan analisis keuangan dengan melakukan analisis varians pada target pendapatan tahun 2015 dan tahun 2016. Analisis varians dilakukan untuk mengetahui apakah aktivitas penjualan sudah dilakukan dengan efektif. Aktivitas penjualan yang efektif akan berdampak pada pencapaian target penjualan.

3. Perusahaan belum pernah melakukan pemeriksaan operasional sebelumnya. Dengan dilakukannya pemeriksaan operasional dapat mengevaluasi efektivitas aktivitas penjualan Hotel Alqueby. Penulis membuat beberapa rekomendasi yang diharapkan akan mengatasi kurangnya efektivitas dari aktivitas penjualan. 


\section{Saran}

Berikut ini beberapa saran yang diharapkan dapat dilakukan oleh manajemen untuk dapat meningkatkan efektivitas aktivitas penjualan pada Hotel Alqueby:

1. CEO sebaiknya membagi tugas dengan direktur seperti direktur merangkap sebagai accounting, CEO sebagai human resource department untuk perekrutan pegawai baru dan supervisor front office.

2. Untuk mengatasi masalah segregation of duties yaitu front office yang merangkap menjadi resepsionis, kasir, dan pencatatan, penulis menyarankan agar CEO melakukan pengecekan setiap hari antara data kunci elektronik yang dibuat melalui program Hune dengan data check-in yang diinput pada program komputer. Sebaiknya program komputer check-in dibuat terintegrasi dengan komputer CEO sehingga CEO dapat dengan mudah melakukan pengecekan. Bila terdapat data yaitu kunci dibuat tetapi tidak ditemukan pada data check-in pada program komputer, maka telah terjadi penjualan ilegal yang dilakukan oleh front office.

3. Untuk mengatasi kegiatan promosi yang kurang dilakukan, sebaiknya Hotel Alqueby melakukan perekrutan untuk staff divisi pemasaran sehingga kegiatan pemasaran dapat ditingkatkan misalnya melalui iklan di radio, brosur, spanduk dan sebaiknya Hotel Alqueby menyusun strategi pemasaran dan meyusun anggaran.

4. Sebaiknya Hotel Alqueby meningkatkan program komputernya. Sebaiknya formulir registrasi, bukti pembayaran dicetak melalui program.

5. Pegawai harus mengerjakan tugasnya sesuai dengan prosedur yang berlaku dan setiap pegawai harus melaporkan hasil pekerjaannya kepada CEO setiap hari sehingga CEO akan mengetahui bila terdapat pelanggaran prosedur.

6. Penulis menyarankan agar kursi pada ruang tunggu lobi ditambah sehingga tamu dapat duduk ketika menunggu melakukan check-in.

7. Sebaiknya breakfast dibagi-bagi per lantai karena masih terdapat lahan kosong pada lantai dua dan tiga cukup untuk tempat kursi dan meja untuk breakfast.

8. Sebaiknya dibuat kebijakan mengenai pembayaran uang deposit sebesar Rp100.000 ketika tamu melakukan check-in.

9. Sebaiknya dibuat target penjualan baru dengan lebih memperhitungkan faktor low season dan high season.

\section{Daftar Pustaka}

Anggraeni, C. V; Dzulkirom AR, M; \& Rahayu, S, M. (2014). Analisis Sistem dan Prosedur Akuntansi Jasa Penjualan Kamar dan Jasa Restoran Hotel Dalam Upaya Peningkatan Pengendalian Intern. Jurnal Administrasi Bisnis (JAB), Vol. 12 No.1.

Aprilia, N, R; Nazar, M, R; \& Zultilisna, D. (2016). Pengaruh Audit Operasional dan Pengendalian Internal Terhadap Kinerja Perusahaan (Studi Kasus Pada Hotel Inna Bali). Jurnal Akuntasi, Vol. 17, No. 2.

Arens, A. A.; R. J. Elder;\& M.S. Beasley. (2012). Auditing and Assurance Service: AnIntegrated Approach (14 ed). New Jersey: Pearson Education Limited.

Bianchi M., Boyle M., Hollingsworth D. (1999). A comparison of methods for trend estimation. Applied Economics Letters.

Endar, S., \& Sulartiningrum, S. (1996). Pengantar Industri Akomodasi dan Restoran. Jakarta: Gramedia Pustaka Utama.

Fengky, H; Sabijono, H; \& Kalalo, M. (2019). Evaluasi Penerapan Sistem Pengendalian Internal Penerimaan Kas Pada Hotel Yuta Manado. 
Jurnal Riset Ekonomi, Manajemen, Bisnis, dan Akuntansi, Vol. 7, No. 1. Manuaba, I, A, D, P; \& Muliartha RM, K. (2019). Pengaruh Audit Operasional dan Pengendalian Internal Terhadap Kinerja Karyawan. Jurnal Akuntasi, Vol. 28.1.

Mulyadi. (2002). Auditing.Edisi 2. Jakarta: Salemba Empat.

Rajagopal. (2008). Team performance and control process in sales organizations. Team Performance Management - An International Journal.

Rangkuti, F. (2009). Strategi Promosi yang Kreatif dan Analisa Kasus IntegratedMarketing

Communication. Jakarta: PT Gramedia Pustaka Utama.

Reider, R. (2002). Operational Review:Maximum Result at Efficient Cost (3 ed). Canada: John Wiley and Sons, Inc.

Romney, M.B., \& P.J. Steinbart. (2012), Accounting Information Systems (12 ed). New Jersey: Pearson Education Limited.

Sawyer. (2012). Guide For Internal Auditors. Altamonte Springs: The Institute of Internal Auditors Research Foundation.

Sekaran, U., \& R. Bougie. (2013). Research Methods for Business (6 ed). New York: John Wiley \& Sons, Inc.

Sugiarto, E. (1996). Hotel Front Office Administration. Jakarta: Gramedia Pustaka Utama.

Sugiarto, E. (2003). Pengantar Akomodasi dan Restoran untuk Anda yangBerkecimpung dalam Industri Pariwisata. Jakarta: Gramedia PustakaUtama.

Swastha, B. (2014). Manajemen Penjualan. Edisi 3. Yogyakarta: BPFE.

Utama, I. G. (2016). Pengantar Industri Pariwisata. Yogyakarta: Deepublish Publisher.

Widjajanto, N. (2001). Pemeriksaan Operasional Perusahaan. Jakarta:
Fakultas Ekonomi Universitas Indonesia 